\title{
GLOBAL JOURNAL OF
}

\section{Community Psychology Practice}

\section{PROMOTING COMMUNITY PRACTICE FOR SOCIAL BENEFIT}

\section{Strengthening community psychology in Europe through increasing professional competencies for the new Territorial Community Psychologists}

\section{By Donata Francescato ${ }^{1}$ and Bruna Zani ${ }^{2}$}

Keywords: Territorial Community Psychologist, critical community psychology, activism

Author Biographies: Donata Francescato (www.donatafrancescato.it) was introduced to Community Psychology in 1970 doing an internship in Quincy Mass, and was an activist in the women's movement in Boston. After receiving her Ph.D. (U. of Houston 1972) she went back to Italy where she wrote the first Italian textbook on CP and funded Effe, a feminist magazine (1972-1982) now available online www.efferivistafemminista.it. She was the first Italian Full Professor of Community Psychology at Rome Sapienza University retiring in 2014. She also funded the European Network of Community Psychologists (ENCP) and the European Association Community Association (ECPA). In 2013 she was given an ECPA award for "advancing CP both in Italy and in Europe, and for her unique contribution to the development of specific intervention and research methods involving community profiles and organizational analysis". She is author of 24 books, 150 papers and of the chapter on globalization in the APA Handbook of CP. Email (mc0938@mclink.i) Bruna Zani (www.unibo.it/docenti/bruna.zani.it) is full professor of Social and Community Psychology at the University of Bologna (Italy), where she was Dean of the Faculty of Psychology (20022008) and Head of the School of Psychology and Education (2012-2015). From 2008 to 2012 she was President of the Italian Community Psychology Society. Since 2006, she has been a member of the Executive Committee of the European Community Psychology Association (ECPA), and since July 2015 she has been a member of the Executive Council of EFPA (European Federation of Psychologists' Associations). Her research interests are on risk and healthy behaviours in adolescence; risk perception and risk communication;

\footnotetext{
1 University La Sapienza, Rome, Italy

2 University of Bologna, Bologna, Italy
} 


\section{Global Journal of Community Psychology Practice}

Volume 8 , Issue 1

service learning; wellbeing promotion; community development; civic engagement and political participation of adolescents and young people. On this latter topic, she has edited a book with M. Barrett, Political and civic engagement. Multidisciplinary perspectives, Routledge, London, 2015. Email (bruna.zani@unibo.it)

Recommended Citation: Francescato, D. and Zani, B. (2017). Strengthening community psychology in Europe through increasing professional competencies for the new Territorial Community Psychologists. Global Journal of Community Psychology Practice, 8(1), pages 1-14. Retrieved Day/Month/Year, from (http://www.gjcpp.org/). 


\title{
Strengthening community psychology in Europe through increasing professional competencies for the new Territorial Community Psychologists
}

\author{
psychology in Europe.

\section{Introduction} \\ The purpose of this paper is to contribute to \\ the heated debate that took place during the \\ seminar of the European Community \\ Psychology Association (ECPA) held in Lisbon \\ in November 2015. The discussion \\ concentrated on the merits and drawbacks of \\ different roles community psychologists \\ should play, as "political activists" or \\ "practitioners." We first discuss the "political \\ activist" model proposed by critical \\ community psychologists and the specific \\ competencies needed to play this role. We \\ then illustrate the recent passing of regional \\ laws in Italy that create the new figure of the \\ "territorial community psychologist," who \\ works directly with the services of city \\ municipalities. We describe which tasks they \\ assign to these territorial community \\ psychologists and outline the competencies \\ needed to perform the tasks these laws \\ mandate. Then we discuss if in Italy we need \\ to make further progress in our training of \\ community psychologists to better prepare \\ them for this new role of territorial \\ community psychologists. Finally, we \\ consider if an integration of critical \\ psychology and mainstream community \\ psychology could contribute to strengthen \\ community psychology in Europe.
}

Abstract

In this paper, we first discuss the "political activist" model proposed by critical community psychologists and the specific competencies needed to play this role. We then illustrate the recent passing of regional laws in Italy that create the new figure of the "territorial community psychologist," who works directly with the services of city municipalities. We outline the tasks the new laws assign to these territorial community psychologists and describe the competencies needed to perform the tasks these laws mandate. Then we discuss if in Italy we need to make further progress in our training of community psychologists to better prepare them for this new role of territorial community psychologists. Finally, we consider if an integration of critical psychology and mainstream community psychology could contribute to strengthen community

\section{The Political Activist Model Postulated by Critical Community Psychology}

Critical Community Psychology (CCP) aims to promote better life conditions from an ecological, value-based, and justice-oriented perspective (Nelson \& Prilleltensky, 2010), pursuing social justice, fighting wars and oppression. (Arcidiacono \& Procentese, 2010). In fact, as Burton, Boyle, Harris, \& Kagan (2007) have pointed out:

CCP is a framework for working with those marginalized by the social system that leads to self-aware social change with an emphasis on value based, participatory work and the forging of alliances. ... CCP is one alternative to the dominant individualistic psychology typically taught and practiced in the high-income countries. It is community psychology because it emphasizes a level of analysis and intervention other than the individual and their immediate interpersonal context. It is community psychology because it is nevertheless concerned with how people feel, think, experience, and act as they work together, resisting oppression and struggling to create a better world. (p. 219) 


\section{Global Journal of Community Psychology Practice}

Volume 8, Issue 1

Recently Prilleltensky and colleagues (2016) have developed a multidimensional model of wellbeing, namely the I COPPE model. This novel tool considers wellbeing as a multifaceted construct composed of seven domains, that is: Interpersonal, Community, Organizational, Physical, Psychological, Economic and Overall Well-being. CCP aims to redefine current social, economic, and political systems as well as to build new ways of living. According to Kagan et al. (2011), to reach these goals, community psychologists should commit to political engagement at the local, national, and international levels. Community psychologists should support individuals, groups, organizations, or movements that are working to oppose inequality and disempowerment, to promote action on global warming and to protect the environment, and to fight for quality public services and against privatization of national health services.

\section{Strategies and tools for action}

The four key strategies of critical community psychological action for change are:

1. Furtherance of critical consciousness (coscientization), including problematization, experiential learning, capacitation, and deideologization;

2. Creation of new forms of social relations and settings, including multidimensional nature of social situations, behavior settings, new or alternative social settings;

3. Making links and the development of alliances and counter systems;

4. Accompaniment, advocacy, and analysis of policy.

Critical community psychologists use a variety of tools to analyze local communities: community audit, community profiling, observation, and community walks. Other tools are stakeholder analysis, decisionmaking, PANDA (participatory appraisal of needs and development of action), SWOT (strengths, weaknesses, opportunities, threats) analysis, force field analysis, visioning (PATH process: Planning Alternative Tomorrow with Hope), and mixed methods (Kagan et al. 2011).

\section{Competencies required fulfilling the role of activist}

Based on the work of liberation psychology, which puts at the center of the theory the concepts of oppression, liberation, and social justice, Watts and colleagues (2003) pointed out that critical consciousness and empowerment develop concurrently through action, leading the person over time to become an activist:

The activist is a person who acts strategically with others, on the basis of shared values, to create a more just society. The strategies include changing how society or its institutions operate (reform, evolution) and creating new institutions or a new society on the basis of alternative principles (revolution, transformation). Methods and tactics include political participation, pressure tactics aimed at gaining concessions, armed struggle, or operating an organization with a mission of social change or liberation. These methods require knowledge, skills, and capacity; so, activism also includes methods at building capacity through community organizing, training, educating, and mobilizing. (Watts et al., 2003, p.188)

In addition to methodological skills,

Community critical psychologists need to have skills in interpersonal relationships, including active listening and other communication skills, such as team work, group process facilitation, taking the perspective of the "other", and bearing witness to oppression... partnership must be based on trust and mutual respect...it 


\section{Global Journal of Community Psychology Practice}

Volume 8 , Issue 1

March 2017

is preferable to acknowledge power

imbalances." (Nelson et al., 2004, p.3)

Other skills needed include the ability to talk in public, to spread ideas through old and new media (print, television, internet sites, blogs, and interventions in social networks like Twitter, Facebook etc.), to organize manifestations, and to write press reports. These skills are currently not taught in most community psychology university programs. Some students learn them by shadowing a teacher who is interested in one or more broad social problems like violence on women, unemployment, and migrants.

\section{The Professional Role Model as Viewed by Policy Makers: Tasks Assigned to Territorial Psychologists by Recent Laws in Italy}

Academic community psychologists who are paid by universities or research centers, can teach, perform innovative research and dedicate much of their time also to the activist role promoted by critical community psychologists. However professional community psychologists, whether selfemployed or working in community services or associations, must pursue more specific and limited goals, working on projects for which they can be paid, since they need to earn a living as community psychologist practitioners (Francescato \& Zani, 2010). One way to know what competencies are required and wanted is to explore what policy makers, through local laws, would like community psychologists to do. Therefore, in this part of our paper we will discuss the recent passing of two regional laws and one city law in Italy that create a new figure of the "territorial community psychologist" who works directly in municipalities, documenting which tasks the laws assign to these territorial community psychologists.

\section{The Basilicata Law (2007)}

The first regional law that introduces the figure of the "social community psychologist" was passed by Basilicata, a small region in Southern Italy in 2007. The aim of this law was to insure "Continuity of response to the needs of support, care, assistance, health and wellbeing of persons and families through the coordinated involvement of institutions and services of local communities."

The passing of this law was actively promoted by local psychologists who studied community psychology in Rome and disseminated among colleagues some community psychology textbooks (Francescato \& Ghirelli 1988; Francescato, Tomai \& Ghirelli 2002). They represented a small minority of Basilicata's psychologists, who work mostly as psychotherapists in private practice or as clinical psychologists in health services. However, some of these Rome-trained psychologists also worked in local cooperatives and became more aware of the need to use a community approach to deal with the many social problems in their areas. Southern Italy, a less developed part of the country, was beset by high unemployment and poor quality social and health services. They became active in local politics, and gained the trust of local politicians, persuading them that community psychology approaches were needed. Acting as consultants, they even wrote parts of the regional social assistance plan policy makers were preparing. Their activism proved fruitful. The regional socio-assistance plan for 2000-2003 instituted a Municipal Social Service, which was required to provide a social worker for every 5,000 inhabitants and a social community psychologist for every 12,000 inhabitants, working at least 18 hours per week. The law of 2007 built on the regional socio-assistance plan for 2000-2003, and prescribed that social community psychologists should conduct community analysis to assess strengths and problems, conduct focus groups, and perform organizational analysis of institutions, associations and groups operating in the community. Moreover, the social community 


\section{Global Journal of Community Psychology Practice}

Volume 8 , Issue 1

psychologist should activate empowerment processes for individuals, groups and organizations.

\section{Strengths and weaknesses emerged in the implementation process}

The major strength can be found in the fact that more than 70 psychologists were hired in different municipalities of the region, grouped in thirteen geographical areas, which varied in the number of municipalities they included. Basilicata has two major towns: Potenza and Matera, and many small towns and villages spread around a wide mountainous territory with winding roads which do not allow for easy travel. Being hired by municipalities allowed psychologists working in these areas to enjoy greater autonomy to plan their activities responding to local needs. However, psychologists hired in certain areas, which included several small municipalities, ended up having only a few hours each month for each municipality since they spent so much time traveling from one location to the other. Moreover, periodic monitoring and evaluation of activities performed by psychologists in different areas showed that passing a law was a necessary step, but it did not guarantee that psychologists performed community psychologist activities prescribed by the law for two important reasons: 1) time needed for urgent issues overtook social community psychology activities and 2) not enough of the psychologists who were hired had the needed training.

First, most psychologists found they had to deal with a myriad of different kinds of "emergency" problems, having to offer consultation to residents facing disability, old age, drug dependency, family conflicts, and adoption issues. More recently they also had to counsel migrants and refugees, who had been assigned to reside in different localities. Since most psychologists had been hired on a part time basis, with only twenty hours a week to spend in more than one locality, they
March 2017

quickly found that once they dealt with these emergencies, they had little time left to perform community analysis, focus groups or organizational analyses. Second, in Italy most psychologists are trained as clinical psychologists and psychotherapists, and few learn community psychology methodologies; therefore, only about $10 \%$ of the psychologists hired by the municipalities carried out community psychology activities. The psychologists who did use some community psychology methodologies all had at least some training in community psychology skills in master's programs or in private institutes training psychotherapists which also offered community psychology courses. Basilicata's psychologists have become fully aware that passing a law is an important first step, but if the psychologists hired in the municipalities, do not know community psychology intervention methodologies, they will spend most of their time doing counseling at an individual or family level.

The Regional Order of Psychologists of Basilicata is therefore now trying to increase the number of paid hours for each psychologist working in municipalities. It has also started a training program to teach community psychologists skills to both psychologists already employed in the municipalities and to young psychologists who aspire to work there. In the fall of 2015 the Order promoted a three-day workshop with Donata Francescato on community analysis, networking, organizational, and empowerment methodologies aimed at individuals and small groups. About fifty psychologists, half of whom had almost no knowledge about intervention methodologies of community psychology, participated in the workshop and asked for further training opportunities.

\section{The Campania Law (2013)}

In August 2013, the region of Campania, situated in southern Italy, including Naples as 


\section{Global Journal of Community Psychology Practice}

Volume 8 , Issue 1

the main city, passed regional law n.9. This

law instituted a Service of Territorial

Psychology to guarantee that citizens of region Campania could have access to psychological services necessary to meet their needs. It mandates that single municipalities or groups of municipalities institute in their Social Plan Unit, a Service of Territorial Psychology, in which at least one psychologist is present for every ten thousand inhabitants.

The Service of Territorial Psychology has these aims:

a) To contribute to the relational wellbeing of people who live in the territory, to tackle and prevent relational problems in families, schools and in the community;

b) To promote the full and harmonic development of the individual in family, work, friendship, leisure time, associative and community contexts.

To reach these goals the service of territorial psychology intervenes with the following activities:

a) Support of residential and day structures for people with disabilities or social problems;

b) Assistance to centers for battered and abused women;

c) Protection of those who are likely to become victims of physical, sexual and psychological violence;

d) Support of family with members with disabilities;

e) Assistance to multiproblem families at high risk of implosion;

f) Support of families in the adoption processes;

g) Support of minors and adults who have penal legal problems;
March 2017

h) Promotion of full psycho-social integration of immigrants and refugees;

i) Consultation with schools and planning of activities to promote school wellbeing, successful academic achievement, prevent school dropout, diminish youth discomfort and risky behaviors.

This law was strongly promoted by psychologists who were activists for a shelter for abused women, and by community psychologists trained at Naples with Caterina Arcidiacono and Fortuna Procentese. They organized several innovative community psychology laboratories, who put students in contact with key figures in the community, including local politicians. Having access to some politicians involved in policy making and having the opportunity to influence their thinking was an important factor in passing the law instituting the role of territorial psychologist. Only a brief period elapsed since the law was passed and we do not yet have evaluation reports on how territorial psychologists have fared.

Promoting a new law to institute a territorial psychologist in Udine (2016)

The experience currently under way in Udine and nine municipalities of the Region FriuliVenezia Giulia (located in the north east of Italy) is very interesting for several reasons. First, also in this region, the Regional Order of Psychologists has been playing a leading role in promoting the passing of a new law. Learning from the experience in Basilicata, the Order has also taken some steps to spread community psychology values and theoretical principles among its members, who are mostly clinical psychologists and psychotherapists. Particularly the Order's board has become keenly aware of the need to teach community psychology skills to psychologists who want to work as territorial psychologists. The basic assumption guiding this project is that before the law is passed it is necessary to promote a cultural change 


\section{Global Journal of Community Psychology Practice}

among psychologists and the public to favor acceptance of the new role of territorial psychologists.

The Order has created a "Community Psychology Task Group" composed of members of local universities, local politicians and members of community associations. They also decided to experiment this new territorial role in Udine and nine other nearby small municipalities by signing a formal agreement that provides that volunteer psychologists will work for four hours a week in each of these nine municipalities in deprived neighborhoods. Meanwhile they are also trying to create a master's in community psychology to train the territorial psychologists who will work in the municipalities when the law will pass.

In April 2016, the Order held a press conference to publicize the formal agreement reached with the nine municipalities, explaining why psychologists need to work in the territory, leaving the walls of their private study, where mostly they are engaged in individual and family counseling or psychotherapy. Local print and television media gave ample reports explaining why there is a need for community psychology approaches in their territory. The Community Psychology Task Group also promoted a conference, in which different speakers talked about community psychology principles and intervention methodologies focusing particularly on how one can promote personal, groups, organizational and community empowerment. In the same day, a workshop with Donata Francescato was also offered on how to increase personal empowerment, and on how to use traditional (radio, TV), Internet and social media (Facebook, Twitter) to increase personal and small group empowerment and decrease unwanted media influence in our lives.

The Community Psychology Task Group released during the April 2016 Conference, a first draft of what they considered appropriate activities for a territorial psychologist to perform, based on the acquired competencies. He/she should:

1) Analyze the needs and resources, and the future perspectives of a territory using community analysis techniques such as community profiling;

2) plan intervention programs through participatory action research;

3) evaluate services and intervention programs;

4) offer brief consultation services for empowering individuals, families, and groups;

5) increase the organizational empowerment of community organizations, associations, and schools using appropriate participatory multidimensional methodologies;

6) promote networking among local groups, institutions and associations;

7) explore alternative and innovative ways to answer specific local needs;

8) mediate social conflicts occurring in different life contexts (education, work, leisure time, etc.)

9) Promote and implement empowerment, socio-affective, and peer education training programs for specific community groups (such as children, youth, old people, migrants, women, and sports mentors).

The Community Psychology Task Group members were trained in Rome with Donata Francescato and Manuela Tomai, and in Bologna with Bruna Zani and Cinzia Albanesi. Moreover, the members were also activists in local associations in Friuli, and they had positive relations with some local politicians of different parties.

Main activities assigned to territorial psychologists in all the three laws 


\section{Global Journal of Community Psychology Practice}

All three laws give strong emphasis on preventive activities and particularly on building strengths and improving relational wellbeing in all the major areas of citizens' lives. All three also mandate supporting individuals and families who are already facing specific problems. Lawmakers seem to be strongly aware that the recent economic crisis has worsened the lot of the poorest and most marginalized groups of citizens, living in contexts already beset by environmental, social and political problems. The differences between poor and rich, migrants and natives, together with the generational and gender gaps, create multilevel problems that are best handled through a community psychology approach. At the core of these divides is the issue of how to relate to the "other" and how to build positive relationships. The passing of these laws with their emphasis on promoting relational wellbeing at the individual, family, small group, organizational, and community levels gives territorial community psychologists a chance to give an important contribution in this direction.

The laws passed in Basilicata and Campania and the one being promoted in Friuli, share several common activities of the territorial psychologists. All three want territorial psychologists:

1) to perform community analysis and promote networking among the institutions, associations, and services of their municipalities, increasing the active participation of citizens;

2) to empower organizations in the community and to organize specific empowerment training programs for groups of citizens (such as children, youth, older people, and migrants), to promote relational wellbeing; and

3) to intervene to support residents who face specific difficulties, such as migrants, conflictridden families, families with members who have special needs (handicap, adoption, penal legal problems etc.).

In all three regions, laws were promoted by some community psychologists who acted both as political activists and as professional community psychologists, spreading community psychology values and participatory intervention methodologies.

We now turn to examine whether existing community psychology training programs in Italy promote the competencies and the intervention methodologies required to perform the tasks these new laws assign to territorial community psychologists.

\section{CP competencies that are already present in Italian training programs and those that need to be further developed}

\section{Practice competencies included in most Italian CP programs}

One main competency already established in Italian CP is action research, or participatory action research. Other frequently taught skills are program planning and evaluation. Moreover, quantitative and qualitative data analyses are learned in most academic CP programs. These competencies will help territorial community psychologists to plan intervention programs through participatory action research, and to evaluate services and intervention programs as these new laws prescribe.

Another core competence that is currently taught in most community courses is small group management. In community psychology, group dynamics management is crucial since most of our interventions (from action research to program planning and evaluation, and from consultation to empowering organizations and communities) are very often done in small groups. Networking among groups to promote bonding and bridging social capital also requires an understanding of small group processes. In some universities, empowering 


\section{Global Journal of Community Psychology Practice}

group workshops are offered face-to-face and online to help students to evaluate the weak and strong points of group functioning; to understand which functions assist group processes and tasks and which hinder group development. Students in these workshops also consider the advantages and disadvantages of various methods of decision making, problem solving, and conflict resolution. An important component is sharing these competencies with members of established community groups aiming to empower them to meet their goals. Another important learning objective is how to promote new self-help groups needed in the community and how to assist members in their first three or four meetings. These group competencies will be much needed by the new figures of territorial community psychologists.

Competencies, skills and tools that are offered in some Italian programs that need to become more widely taught and used

Some of the competencies and skills the new laws require are not taught in all Italian community psychology programs. In some graduate programs, students learn how to promote partnerships with public institutions at the regional and local level, and to network with unions, schools, police departments, and volunteer organizations of all kinds, creating and implementing integrated intervention programs (Zani, 2012). Obviously, this particular competency will be especially useful for territorial community psychologists working directly with politicians and administrators at the local level, but training in this competency is not universally available. For example, here we describe four competencies in more detail that need to be more widely learnt to prepare territorial community psychologists for the tasks the laws ask them to perform.

Community Profiling and Network Building

Through participatory action research, territorial community psychologists can find out what problems and strengths characterize a local community for different groups of residents and identify their most desired changes. This community profiling includes examining eight domains: territorial, demographic, economic, service, institutional, anthropological perceptions, psychological perceptions, and visions of the future. First a core research group made up of experts in each profile domain is formed and then interviews with these experts are performed. Next, special focus groups with dominant and marginalized groups in the community are carried out to explore perceptions, emotions, desires, and fears for the future of the community.

In each focus group, first a preliminary analysis is carried out: participants use brainstorming techniques to come up with positive and negative aspects of their community. Each comment is then classified as primarily belonging to one of the eight profile domains. This allows researchers to determine which community profiles are perceived as more problematic and which are perceived more positively. It also gives a first measure on how empowered or disempowered participants perceive their communities to be: if more positive points are mentioned, this is an indicator of a perceived empowered community; if more negative comments appear, it is an indicator of a perceived disempowered community.

The focus groups lead to a creation activity where participants are invited to develop a plot for a movie script about their community. After this creative phase and the presentation of its results through narration and dramatization, group members are invited to discuss their movie script contents, including the emotions they experienced and portrayed in the narratives together with the problems and strengths that emerge from their narrative about their community. Participants then focus on the future of the community, and members discuss: 


\section{Global Journal of Community Psychology Practice}

a) how they imagine their community in ten years, b) their major fears, and c) what they desire most for the future of their community. In the final discussion, members of the focus groups outline possible solutions to identified problems and how to obtain desired changes in their community. Once the focus groups discussions conclude, there is a presentation of all results in large public meetings during which participants formulate the main priorities for change, identifying which strong aspects of the community they can count on to obtain desired changes in the most problematic aspects identified. Specific activities that need to be performed to achieve desired goals are also outlined. (For more details about how this methodology was developed, including several other European countries see Arcidiacono, Tuozzi \& Procentese, 2016; Ehmayer in press; Francescato \& Mebane, 2015; Francescato \& Zani, 2013)

\section{Participatory Multidimensional Organizational Analysis (PMOA)}

Empowering organizations and associations in a community is a crucial aim for territorial community psychologists since they affect personal, relational, and collective wellbeing for all members of a local community, who spend a large portion of their life in them. Italian community psychologists have developed a specific methodology to promote organizational empowerment. It is called Participatory Multidimensional Organizational Analysis (PMOA).

Using PMOA, individuals representing all hierarchical levels of large organizations (e.g. students, parents, teachers, janitors, and office staff in a school setting) or all members of small ones (fewer than 30) analyze their organization across four dimensions; structural-strategic, functional, cultural, and psycho-environmental. Examining the structural strategic dimension, the participants: a) explore the strategic history of their organization (i.e., when it was born, what goals and visions it had, how strategic goals have changed over time); b) assess organizational performance using specific criteria (positioning, etc.); and c) define strategic objectives for the immediate future and for next five years. Analyzing the functional dimension, participants outline tasks needed to reach strategic aims and deal with emergencies. Additionally, they examine activity flows and detect points of strengths and problem areas using methodologies from sociology and organizational disciplines. The cultural dimension explores group and individual emotional variables using tools from cultural psychology, cultural anthropology, and socio-analysis. Group drawings, recurrent jokes, pictures hung on walls, are often used. To capture problemsolving styles, the movie script technique is also employed. The psycho-environmental dimension explores the fit between individuals' expectations and organizational pressures, using tools from organizational psychology to measure leadership styles, communication, and conflict resolution patterns. Participants state preferred functions they may want to exercise in the future and whether they have the skills needed or if they need further training. Evaluation of the efficacy of PMOA has been carried out on 140 organizations ranging from unions to schools, from volunteer organizations to hospitals, from small family firms to governmental organizations (For more details in English and Spanish on the development of PMOA, see Francescato \& Aber, 2015; Francescato \& Zani, 2013; Francescato, Tomai \& Mebane, 2006).

These new organizational empowering tools have spurred considerable interest in the global CP community; Italian community psychologists have been invited to hold workshops in several European countries, in South Africa, and in Latin America. Additionally, these efforts have had some practical effects on academic CP training. Arcidiacono (2013) found that, compared to 


\section{Global Journal of Community Psychology Practice}

the nineties, more courses on organizational empowerment were offered in European CP programs and more chapters on the topic appear in several recent CP textbooks, especially in Germany and Italy. However, organizations remain a minority or neglected topic in most CP programs worldwide. Recently there has been an increase in interest in the USA, with the publication of three special issues in the Journal of Community Psychology. Organizational empowerment is a topic that needs to become more included in university $\mathrm{CP}$ courses to ensure that future territorial community psychologists will have the knowledge and skills necessary to promote organizational empowerment in their communities.

\section{Sociopolitical empowerment training}

Sociopolitical empowerment labs integrate concepts and tools from the affective education movement, feminist consciousnessraising groups, critical community psychology, and mainstream community psychology. They explore the congruence between personal desires and competencies and what the outside world offers. These labs have participants focus first on reflecting how our needs and wishes are influenced by the specific mass media we use daily and by those available to us during our early adolescence (favorite songs, movies, internet sites etc.). Then participants examine the political socialization experienced in family, peer groups, school, and specific mass media and social networks, and how one can use media to actively promote desired changes. They detect the strong and weak points of the small groups of which they are members, and, using short versions of PMOA and community profiling, they explore opportunities and problem areas in these territorial contexts. Finally, they select priorities for personal change that they can manage on their own. For desired collective changes, participants identify other people, groups, and/or institutions with which they may network to achieve these wider goals (Francescato et al., 2009, Francescato \& Zani 2013)

These empowerment methodologies could be very useful for territorial community psychologists who are asked to develop specific empowerment training programs for groups of citizens such as migrants, women, children, youth, and older people. Combining some of these methodologies, such as community profiling, PMOA and sociopolitical empowerment training, can give a strong contribution to the goal of "promoting the full and harmonic development of the individual in family, work, friendship, free time, associative and community contexts" as the Campania law codifies.

Community profiling, PMOA, and sociopolitical empowerment training competencies can be taught through Computer Supported Collaborative Learning as we have verified in several pilot studies which have been summarized in a book chapter available online in English (Francescato, Mebane, Tomai, Benedetti, \& Rosa, 2012). In fact, we strongly recommend consideration of the opportunities provided by virtual communities to train territorial community psychologists who may also decide, depending on local needs, to choose social networks and virtual communities as a new potential intervention setting.

Consulting and giving aid to people already suffering from different forms of deprivation and malaise using critical community psychologists' insights

In Basilicata, most of the time of the territorial community psychologists was taken up by emergency consulting and counseling to individuals and families. The Campania law specifically states that the territorial community psychologist should intervene to help people with disabilities; abused women, people who are likely to become victims of physical, sexual and psychological violence, families at high risk of 


\section{Global Journal of Community Psychology Practice}

implosion, minors and adults with legal penal problems; and immigrants and refugees. Most Italian psychologists are trained as clinicians so they have some consulting and counseling skills. However, the territorial community psychologists should focus more on using brief, future oriented, political consciousness raising and empowerment counseling. Therefore, they may need more specific training to perform this type of empowerment counseling, which is partially based on critical psychology political awareness building (Francescato \& Zani 2013).

\section{Conclusions}

To strengthen community psychology in Europe we should integrate both critical community psychology insights and improve the competencies and skills of practicing community psychologists so they can perform, for instance, the activities that the new regional laws in Italy assign to the new figure of the territorial community psychologists. Critical psychologists' viewpoints are crucial to raise awareness of the global political, structural, and economic dynamics that contribute to create the marginalization and the suffering of the most vulnerable people. As practitioners, we should select among the many global problems that characterize our present world, the ones which are strongly present in our local contexts. In Europe, for instance, we should privilege empowering interventions for young people who neither work nor study (the NEET generation), for the immigrants from different religious and ethnic groups that require integration, and for women victims of domestic violence. These are huge problems in many European countries, and we have as community psychologists accumulated significant experience in intervening in these specific areas. However, to develop more community programs we also need to become more politically active to convince local politicians to pass laws that create more job opportunities for practicing community psychologists, as has happened in Italy.

Integrating the activist and the practitioner roles will permit us to overcome some of the limits of both roles. Community psychologists who focus primarily on activism often do not recognize the great disparities that exist between the multitude of economic, political, and environmental problems that beset our planet and the means community psychologists must use to solve them. On the other hand, community practitioners sometimes focus too much on local issues, neglecting the broader global roots of various forms of oppressions. To reach integration, we need to show respect to both roles recognizing their limits and their strengths.

\section{References}

Arcidiacono, C. \& Procentese, F. (2010), Participatory research into Community Psychology within a local context, Global Journal of Community Psychology Practice, 1 (2), 1-10.

Arcidiacono, C. (2013) Reflections and actions in community psychology. (ECPA Bulletin n.1) Retrieved from http//www.ecpa-online.eu

Arcidiacono, C., Tuozzi, T., \& Procentese, F. (2016). Community Profiling in

ParticipatoryAction Research. In L. A. Jason \& D. S. Glenwick (Eds.), Handbook of methodologicalapproaches to communitybased research: Qualitative, quantitative, and mixed methods (pp.355-364). New York: Oxford University Press.

Burton, M., Boyle, S., Harris, C., \& Kagan, C. (2007). Community psychology in Britain. In S. M. Reich, M. Riemer, I. Prilleltensky, \& M. Montero (Eds.), International community psychology: History and theories (pp. 219237). New York, NY: Springer.

Ehmayer, C. (in press), How to diagnose a city - The Activating City Diagnosis (ACD) as an innovative tool for participatory urban development. 


\section{Global Journal of Community Psychology Practice}

Volume 8 , Issue 1

Francescato, D. \& Aber, M. (2015) Learning from Organizational theory to Build Organizational Empowerment. Journal of Community Psychology, Vol. 43, No. 6, 717738.

Francescato, D. \& Ghirelli, G. (1988).

Fondamenti di psicologia di comunità. Roma: NIS

Francescato, D. \& Mebane, M. (2015) Learning Innovative Methodologies to Foster Personal, Organizational and Community Empowerment through Online and Face to Face Community Psychology Courses Universitas Psychologica, 14(4), 15-25.

Francescato, D. \& Zani, B. (2010) Community psychology in Europe: more needed, less wanted. Journal of Community \& Applied Social Psychology, 20,445-454.

Francescato, D. \& Zani, B. (2013). Community Psychology Practice Competencies in Undergraduate and Graduate Programs in Italy. Global Journal of Community Psychology Practice, 4(4), 1-12.

Francescato, D., Tomai M. \& Ghirelli, G. (2002) Fondamenti di psicologia di comunità. Principi, strumenti, ambiti di applicazione. Roma: Carocci.

Francescato D., Tomai M., Mebane, M. (2006) Psicologia comunitaria en la ensenanza y la orientacion. Experiencias de formacion: presencial y online. Madrid: Narcea.

Francescato, D., Solimeno A., Mebane, M. \& Tomai, M. (2009) Increasing students perceived political empowerment through online and face to face community psychology seminars. Journal of Community Psychology, $37,7,874-894$.

Francescato D., Mebane M., Tomai M., Benedetti M., Rosa V. (2012). Promoting social capital, empowerment and counterstereotypical behavior in male and female students in online CSCL communities. In: $\mathrm{H}$. Cuadra Montiel (Ed.). Globalization, book 1, Intech, 75-108.
March 2017

Kagan, C., Burton, M., Duckett, P., Lawthom, R., Siddiquee, A. (2011). Critical Community Psychology, Chichester, UK: BPS Blackwell, Wiley.

Nelson, G., Poland, B., Murray, M. MatickaTindale, E. (2004). Building capacities in community health action research. Toward a praxis framework for graduate education, Action Research, 2, 389-408.

Nelson, G. \& Prilleltensky, I. (2010). Community psychology. In pursuit of liberation and well-being (2 ${ }^{\text {nd }}$ ed.) New York: Palgrave Macmillan.

Prilleltensky, I., Dietz, S., Prilleltensky, O., Myers, N.D., Rubenstein, C.L., Jing, Y., \& McMahon, A. (2016). Assessing multidimensional well-being: Development and validation of the I Coppe Scale. Journal of Community Psychology, 43(2), 199-226.

Watts, R.J., Williams, N.C., \& Jagers, R.J. (2003) Sociopolitical development, American Journal of Community Psychology, Vol. 31, No 1-2, pp. 185-194

Zani, B. (2012) (Ed.) Psicologia di comunità: prospettive, idee, metodi. (Community psychology, perspectives, ideas and methods) Roma: Carocci 